\title{
Prophetic witness in weakness: A response to Prof Robert Vosloo from a Pentecostal perspective
}

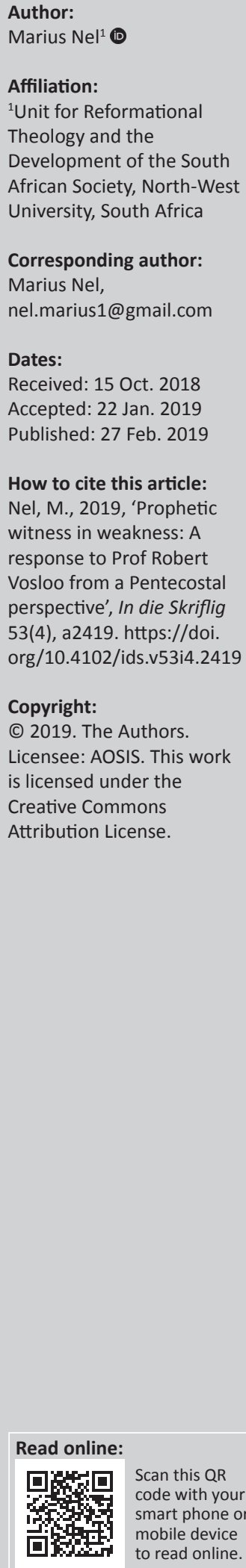

In his article about the prophetic witness of the church, Vosloo emphasises the necessity that it should always be done in solidarity with society to represent the perspective of weakness as a form of performative resistance. In response to Vosloo, this article utilises a Pentecostal perspective to think about the church's prophetic witness. 'Prophecy' means something else for Pentecostals. They hold a non-cessationist or continuationist approach to the Bible, implying that they are committed to a Spirit-centred, miracle-affirming, praise-oriented version of Christian faith where prophets still play an important role. The role of the prophet is defined in two ways: bringing a word from God related to the present situation, and engaging in prophetic politics to help solve society's challenges.

\section{Introduction}

In Reformed and Roman Catholic perspective, two perspectives of prophecy can be found. Firstly, the contemporary prophet is an engaged observer who, in solidarity with particular stakeholders, criticises the actions and policies of other agents from outside as an authentically Christian mode of moral discourse; in De Villiers' definition (2016:154), a representative of the church who provides a socio-political or economic analysis of society, criticising or encouraging current practices. Secondly, the prophetic office is understood as 'the Word of God being preached', referring to the minister's regular proclamation of the gospel. Vosloo's stimulating and thought-provoking article (2019) is about the church's imaginative prophetic witness from this perspective as a witness born from weakness in solidarity with society as performative resistance. ${ }^{1}$

My presupposition is that contemporary prophecy in the Pentecostal movement in its reception and contents stands, in a way, in continuity with the phenomenon of prophecy as found in the Old and New Testament. ${ }^{2}$ These words (at times also underwritten by significant acts, as in biblical times) may represent a form of extra-biblical revelation and prophecy is a charisma $(\chi \alpha \dot{\rho}(\sigma \mu \alpha)$ of the Spirit that requires another charisma, namely the gift of being able to

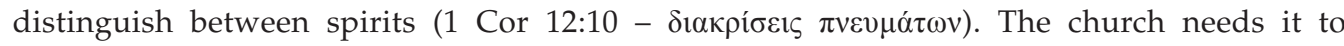
distinguish whether the prophets' words are in accordance with the scopus of God's revelation as found in the Bible. My response to Vosloo is from another perspective: prophetic witness in African Pentecostalism.

That such a perspective also needs to be heard, can be justified when one keeps in mind that, while in 1970 it was estimated that there were 68 million classical Pentecostals, charismatics or neo-Pentecostals in the world, 30 years later there were 505 million, and by 2008 another 100 million were added. The implication is that about a quarter of the world's Christians are Pentecostals. The figure was projected to rise to almost 800 million by 2015 (Barrett, Johnson \& Crossing 2008:30; Jacobsen 2011:50). More than 60\% of Protestants in Kenya, Nigeria and South Africa are Pentecostals (Pentecostal Resource Page 2006), leading Asamoah-Gyadu (2013:32) to call Africa a hotbed of Pentecostal or charismatic activity. ${ }^{3}$ Pentecostalism is big business in Africa and in its diverse forms is fast becoming the representative face of African black Christianity (Kärkkäinen 2002:172). ${ }^{4}$ Africa as a diverse continent with more than 3000 ethnicities, and distinct languages has a significant Pentecostal element.

1.Vosloo (2013:24-25) argues that South Africans should remember their traumatic and painful history in order to establish a 'future-orientated memory'. The church needs to look at the past with new questions and through new lenses in order to bear witness, born from the perception of its weakness and culpability, in order to establish a hopeful vision of a just and shared future.

2.There is not enough space to discuss the issue here (see Nel 2017 for a synopsis of the debate)

3.In Africa, there are 126 million charismatics or members of mainline churches with a charismatic experience (Barrett 2001:409).

4.Omenyo and Atiemo (2006:58) use a typology of African Pentecostalism that takes into account historical and theological categories, making sense of the diversity of Pentecostal denominations, independent groups and movements within Africa. They distinguish between 
Pentecostals' idea of prophecy differs from the common Reformed use. They use the concept prophecy in two senses. The first is in accordance with the use of the concept in the Hebrew Bible of revelations and divine communications being transmitted to the wider body of believers by individuals with special prophetic gifts. Its second use, related to the first, is concerned with the church's function to speak a prophetic word to the powers as part of prophetic politics (Anderson 2001:223). The two concepts are discussed separately before some concluding remarks are made. The phenomenon of African neo-Pentecostal prophecy will be described and some prescriptive remarks about its practice are also made.

\section{Prophecy as a word from God}

The concept of prophecy in the Hebrew Bible is related to and also present in writings of the New Testament (see e.g. Ac 11:27-28; 13:1-2; 21:10-11; 1 Cor 12:28; 14:29-32). Among Pentecostals in all their diversity, prophesying is an essential aspect of the ministry and spirituality - the accepted way in which the Holy Spirit reveals God's will and word for a specific situation (Daneel 1987:25). Much of prophesying serves a distinct pastoral function of providing advice, exhortation or warning to individuals and groups (Anderson 1991:52).

While the Reformed (and Roman Catholic) tradition thinks in cessationist terms, ${ }^{5}$ African Pentecostals understand the prophetic task and ministry primarily in terms of another praxis that plays a determining role in their daily lives and theology. This praxis will be discussed by applying Vosloo's characterisation (2019) of the prophetic witness to it before reference will be made to a Pentecostal prophetic theology of politics with the purpose to evaluate its potential contribution to African society.

\section{Africa and prophets}

A prominent, defining feature of African Pentecostal churches is the category of prophets as leading religious functionaries (along with apostles). Historically, prophecy has been playing a significant role within Pentecostalism with its emphasis on the experience of Spirit baptism and the resultant expectation of the revelation of God's power and prophetic guidance to

5. Hard cessationists posit radical discontinuity between biblical miracles and the present day, despite periodic 'special providences', as cessationists describe events that look like miracles (Keener 2017:275). Most cessationists rule out only regular that look like miracles (Keen supernatural gifting and not special divine activity. Other cessationists argue that although they believe that miracles could happen, they have never seen any. This viewpoint implies that a contemporary practice of prophecy, interpretation of tongues and other charismata of powers and miracles cannot exist as Keene (2017:321) shows. That most Protestants are no longer cessationists is a tribute to the effectiveness of the Pentecostal movement, according to Keener (2017:275).
}

the contemporary believer. African Pentecostalism, however, also partially utilises the African concept of prophecy, changing its intent and content to an important degree and making it possible to distinguish between African Pentecostalism apart from the Pentecostal movement as such. The difference between African and Western Pentecostalism lies in the African Pentecostal churches' orientation to the spirit world consisting of two issues. Firstly, the charism of prophecy has a particular appeal for Africans, because it echoes the traditional African prophetic spirituality that accentuated 'spirit possession', 'divine seizure' and 'supernatural revelations' concerning the spiritual causes of actual events among people as Muindi (2012:211) argues. Cox (1995:219) makes the provocative remark that for any religion to grow in Africa it must be able to include and transform at least certain elements of pre-existing religions that still retain a strong grip on the cultural subconscious and it must equip people to live in rapidly changing societies. These ingredients in Pentecostalism help people recover vital elements in their culture that are threatened by modernisation (Cox 1995:222). Prophecy's fruit is in the personal, communal and predictive nature with the revelation of hidden sins, helping people to overcome their traditional and deep-seated fear of witchcraft and sorcery. It also reveals the will of God in specific situations, reveals what is going to happen, reveals the cause of illness or misfortune and how to counteract it, detects wizardry, and serves a distinct pastoral function of providing advice or exhortation (Anderson 1991:52).

Secondly, African Pentecostal prophecy agrees with a close affinity regarding the Holy Spirit and the charismata, and the existence of evil spirits (Anderson 1991:34). Pentecostal prophetism appropriates the holistic African worldview (Taylor 1963:72) ${ }^{6}$ by focusing on how the spirit world impinges on the visible world to hinder or foster human flourishing. The reason is that challenges such as unemployment, poverty, barrenness and an unhappy marriage, sickness and death have their provenance in the spirit world, and not in physical problems that need secular analysis as viewed by Western society (Ngong 2006:524). In African traditional life birth, illness, death, drought and material challenges were explained as acts perpetuated by good or evil spirits. Human beings were vulnerable and open to both evil and benevolent forces, The ancestors should be appeased because of their influence on the world of spiritual forces. The power of evil was perpetuated by bad witchcraft, ancestral spirits, bad muti or herbal medicines and potions made by sangomas, which were believed to cause misfortune in the lives of people. The powers of evil caused illness, poverty and broken relationships (Frahm-Arp 2016:271; Quayesi-Amakye 2013:51-85). Because people were curious about their existential concerns, they explored sources of vital forces to change their destinies for the better; hence the

6.Taylor (1963) describes the African worldview as a sense of cosmic oneness where func It is a hierarchy of power, but not of being, for all are one all are he upo another. It is a hierarchy of power, but not of being, for all are one, all are here, and all are now supernatural, for nature, human beings and the unseen are inseparably involved in one another in a total community. Within the African worldview, African ideas of the Holy Spirit and the world are not far removed from the biblical revelation, in the opinion of Anderson (1991:5) 
popularity and constancy of prophetism in Africa's religious climate (Quayesi-Amakye 2016:302).

Salvation consisted of freedom from evil powers that hinder human beings from achieving well-being (Ndiokwere 1981:239-243), implying for most Pentecostals that ancestor veneration is not godly and they should break with their extended families who practice ancestor veneration, because they fight against the evil forces of ancestors, witchcraft, evil spirits, hobgoblins and Satan (Frahm-Arp 2016:271-272). African Pentecostal Christians are proud that they have not forsaken the spiritual customs their ancestors passed on to them before the whites came to the continent, even though the Western missionaries encouraged them to abandon the remnants of 'superstition' because of its intolerance of Christian patronage of traditional worship and practices (Quayesi-Amakye 2016:289). They believe that God was already present in Africa before the Europeans arrived and that their way of worshiping is better than the ways the missionaries taught them - which lead to a thorough Africanised version of Christianity (Cox 1995:247). However, all African religious and cultural customs were not accepted uncritically. For instance, defetishisation and pagan circumcision were used to expose and denounce certain aspects of paganism controlled by evil spirits (Kärkkäinen 2002:173).

\section{Prophets and African traditional religions}

African Pentecostalism is based on a primal vision with a sense of cosmic oneness where fundamentally all things share the same nature and humanity, and the unseen are inseparably involved in one another in a total community (Anderson 2016:310). This led to Cox's (1995:247) remark that Pentecostalism's success is partly related to its ability to assimilate a wide variety of African indigenous religious practices and primal worldviews selectively, regaining a pneumatic and charismatic religiosity that contemporary Africans can identify with. African Pentecostals succeed in innovatively appropriating its very experiential and versatile spirituality to serve what Vosloo (2019) calls the 'life-denying realities' of Africans in post-colonial times. Its dream of the coming kingdom of heaven with healing, wholeness and holiness in its wake is linked with intervention in the 'thisworldly' needs of ordinary people in the idiom that they understand and by emphasising the power of the Holy Spirit to provide in any need, illustrating what Vosloo (2019) calls prophetic solidarity with people's existential needs. Pentecostal prophets attract many South African black people for the reason that they comprehend and address the challenges experienced by inter alia the economically marginalised, poor African youth who have lost any hope of acquiring a job, migrants, refugees and others who live amidst the squalor of township and squatter camp inequality. Their pneumatological view of the God of Scriptures, envisaged as present through the Holy Spirit, accounts for the appeal and rapid proliferation of these movements that include pneumatological factors such as the adaptations to traditional rituals and customs, the prophetic practices in detecting and removing malignant medicines and wizardry, and the role of healing and exorcism (Anderson 1991:30-31). In Africa, the message that the power of the Holy Spirit can conquer sickness and the oppression of evil spirits impacts on the psyche of indigenous people, because they experience these problems that pneumatic-set churches offer a solution to. Pentecostal worship also satisfies both spiritually and emotionally while the churches, established by the Western missionaries, make them feel uncomfortable because of the apparent lack of the Spirit in these churches (in the words of Institute for Contextual Theology 1985:27). They argue that missionaries failed to understand the African worldview ${ }^{7}$ and tried to impose Western Christianity on African converts without providing an answer to Africans' concrete physical needs. The neo-Pentecostal churches with their prophets provide Africans with more divine involvement than even their traditional religion did with its African God that was predominantly transcendent rather than immanent - a God who did not interfere with or harass humans and was regarded as 'good' (Mbiti 1969:43-45). What became clear was that it is necessary that the Holy Spirit be allowed to work in a particularly African way among Africans, argues Anderson (1991:46), emphasising that the Holy Spirit has a specifically 'African' way of revealing the Spirit to Africans and implying that the encounter with the Spirit will necessarily be coloured and influenced by the receiver's culture. This African way of working by the Spirit has often been misunderstood by missionaries who brand these manifestations as excesses, manifestations of demons or of the 'flesh', and a groping to traditional religion, implying that the churches practice a syncretism of beliefs.

Research found that the reasons why many indigenous Christians rejected historic mission Christianity were mainly that the missionaries' religion did not have pneumatic elements and was not biblical enough (see Asamoah-Gyadu 2013:161). Historic mission Christians were perceived as neglecting or diluting biblical teachings to suit their liberal lifestyles and their indifference to such truths as the experiences of Spirit baptism and the practice of the charismata. Their religion did not attract many Africans, because it did not solve their daily existential challenges. In African Pentecostalism, the Bible speaks to everyday, realworld issues of poverty and debt, famine and misplacedness, racial and gender oppression, state brutality and persecution. When the Spirit enters one's life, it is like swallowing 'God liquidized', in the words of David Wesley Myland, an early Pentecostal (Jacobsen 2003:1).

Anderson (1996:180) notes that prophecy in African Traditional Religious (ATR) traditionally served as a moral corrective and direction for people who need to embrace the

7.It is a valid question whether it is possible to generalise when one speaks about 'African worldview and traditional religions'. Although ample room should be left for diversity within Africa, it is, howevert thought that appears to pervade Africa in a way that is quite unlike anything perceived in Europe, Asia or the Americas. This makes it possible and viable to speak of 'African traditional thought and religion' in a general way, without denying the particularism of different parts of Africa (Anderson 1991:11). 
future. Bosch (1975:3) suggests that ATR can be described by using three terms: Theism, or the belief in a supreme being (and sometimes lesser gods); spiritism, or the belief in spirits, including ancestors; and dynamism, or the belief in a life-force working through objects and available to some people to utilise for good or evil. Traditional African concepts of God generally emphasise the transcendence of God, resulting in a deusotiosus, a withdrawn, distant supreme being who is not involved in the everyday affairs of people. This implies that it is necessary for the African to access some protection from the spirit world, and it is done traditionally through witchcraft and magic (dynamism) (Anderson 1991:13). In African traditional life, national and personal challenges were explained as acts perpetuated by evil powers and people, curious about the causes of their challenges, explored the spiritual causes of actual events to change their destinies for the better - they visited the diviner. Traditionally diviners provided help, because they could decipher the past through their extra-sensitivity and extra-sensory abilities to perceive spiritual reality. Having identified the cause of the event, a sacrifice of some form was prescribed by them as a way of communicating with the world of spirits, to expiate sins, seek solutions, show gratitude, appease spiritual powers or ask for their support (Omenyo \& Arthur 2013:57-58).

Pentecostal prophets as the contemporary version of the diviners are expected to be able to perform a similar feat by revealing the spiritual world to the believer or provide proof of their power by demonstrating signs and wonders. The difference is that the diviner relies on divinatory slabs, bones or spirits, or some other means, whereas the prophet invokes and speaks exclusively on behalf of the Holy Spirit. Both types of 'divination' concentrate on the personal causation of illness or challenges, which is the existential question foremost in Africans' mind (Anderson 1991:54).

African prophets can offer what it perceives to be God's word or will concerning challenges if their convincing moral core and force is based on prophecy as an alliance with God and in solidarity and identification with society's pain and tragedy, producing imaginative words of God and tested by the faith community in Pentecostal fashion. Prophets who minister the word should be reminded repeatedly that their effectiveness is determined not only by the anointing of the Spirit that rests on their ministry, but also their compassion (Afrikaans, bewoënheid). It is only when they are agitated by the pain and suffering that characterises contemporary society, when their eyes are washed by tears of weakness and empathy that their eyes would be clear to see the direction of God's word and their voices would be heard. The power of God's almightiness should be reflected through the lens of Christ's suffering on the cross where the power of God becomes weakness that challenges and restructures our ideas of power in a secularist sense (Moltmann 1974:12).

I venture to say that Pentecostal prophecy has also become politically influential with quite a few prominent African politicians and other leaders allowing prophets to speak into their lives and providing social critique of norms and values, such as political logic built on military force, energy generation by way of means that contribute to global warming and climate change, an economics of greed, an absence of truth from the political discourse, et cetera. This mostly happens in private and is not public knowledge. Poverty, economic inequality, violence, crime, HIV and AIDS, state capture and xenophobia have become an alternative epistemology that serves as a hermeneutical key with which prophets read and interpret the Bible in accordance with acceptable Pentecostal hermeneutical practice (Anderson 1996:223), operating on the assumption that God wants to meet the needs of his people in a direct manner. These worldly challenges then serve as the hermeneutical key to the interpretation of the Bible, admittedly at times in a historicist way where the social-historical background and horizon of the text is ignored. It is interpreted as though it were written exclusively for contemporary believers.

Pentecostal theology is not only word-based; it includes acts of healing and deliverance based on the belief in the intimate personal knowledge of and participation in God's anguished love for his people (in Katongole's terms, quoted by Vosloo (2019) and God's intervening power that can overcome any evil powers. The Bible is believed to contain answers for these worldly needs (Anderson 2013:224) and prophets operate on the assumption of immediacy that God wants to meet people's needs. Its pneumatological soteriology is expressed in interventionist and mediate terms. In this sense, Pentecostal prophets have become an innovative Christian alternative to traditional healers and diviners.

It is true that there are excesses and abuses perpetuated by some prophets within the neo-Pentecostal movement as Vosloo (2019) explains: prophets who are more interested in making money or serving their own interests than in speaking truth to powers and to believers. They are causing damage to the movement as a whole. These practices enjoy wide attention of the press and mass media, although they represent a few exceptions. One needs to look at the prophetic movement as a whole and evaluate its impact and contribution on society. At the same time, its most prominent leaders should be encouraged to organise the movement to such an extent that it can protect itself from swindlers and charlatans that damage its reputation with the public and government.

\section{Prophetic politics}

The concept of prophecy is used by Pentecostals in two ways: to refer to a word of revelation from God about a specific situation, and a prophetic word spoken by the church to the powers. A part of the function of prophets has become their influence on African leaders as explained. In the last section, the prophetic politics of the Pentecostal movement is discussed in more detail.

Originally, Pentecostals and charismatics did not mix in politics such as many evangelicals do. Their vision of the 
kingdom of God was defined in eschatological terms as a future hope. While they drove out devils, their nations went to the devil, in the parlance of Shaw (1997:292). Their exclusive and ultimate loyalty and obedience to God disqualified them to address the social issues that determined their destiny on earth (Vosloo 2017:150). In describing Pentecostals' long tradition of pacifism and quiescence, Smith (2014:192) describes their apolitical and otherworldly uncomfortableness with relating to wider society or engaging in worldly issues such as politics, while their pietism, eschatology and evangelism contributed to their political quiescence (see Anderson 2013:261; Yong 2010b:333). In many cases, this stance changed over time and they have become more involved in political and economic issues by following the example of the AICs and engaging in prophetic politics. What is necessary is that Pentecostals should balance their dedication to God with their witness in the world.

I agree with Vosloo (2019) that, in light of the complexities of life and socio-political and economic challenges, we may not be exactly sure what the content of our prophetic witness should be, what a word from God would entail. Prophets should be careful when they present their words. They should also campaign for the establishment of the church as an alternative community in the world. Kaunda (2016:8) makes the important remark that any attempt by the church to change society, involves creating new ways of being in the world and new possibilities for socio-economic transformation in order to find a remedy for the persistent social ills of the inequality that characterises African society and, in particular, South Africa. ${ }^{8}$ One of the primary ways neo-Pentecostals can react to this phenomenon is through its practice of prophetic politics. Pentecostal prophets require a prophetic politics informed by Pentecostal spirituality that engages the public sphere boldly. ${ }^{9}$

One way how prophetic politics operate is by way of the efficient charismatic faith community existing as the body of Christ by establishing counter-cultural, counter-conventional communities as a counter-history, counter-ethics and counterontology to that of the myth of secularism (Yong 2010a:228). A charismatic community is one in which the crucified and resurrected Christ is seen (by means of discernible phenomena such as the charismata) to be dynamically and immediately present among his disciples by the power of the Holy Spirit

8.South Africa has one of the highest inequality rates in the world, perpetuating both inequality and exclusion. According to Statistics South Africa, the Gini coefficient measuring relative wealth reached 0.65 in 2014 based on expenditure data (excluding taxes), and 0.69 based on income data (including salaries, wages and (excluding taxes), and 0.69 based on income data (including salaries, wages and
social grants). The poorest $20 \%$ of the South African population consume less than social grants). The poorest $20 \%$ of the South African population consume less than $3 \%$ of total expenditure, while the wealthiest $20 \%$ consume $65 \%$. Based on a
poverty line of $\$ 1.90$ per day at Purchasing Power Parity (PPP), poverty fell from $33.8 \%$ in 1996 to $16.9 \%$ by 2008 . Factors driving these include social safety nets, real income growth as well as decelerating inflationary pressure on households, the expansion of credit and growth in formal housing. Yet, progress has slowed in recent years due to structural challenges and weak global growth since the global financial crisis of 2008. Poverty was $18.9 \%$ in 2015, having increased slightly since 2011 . High unemployment remains a key challenge, standing at $26.7 \%$ in the last quarter of 2017. The unemployment rate is even higher among youths, close to $50 \%$ (World Bank in South Africa 2018).

9.In defining 'public theology', Hansen, Koopman and Vosloo (2011:xv) emphasise that it presupposes that the theologian is clearly knowledgeable and concerned about what happens in public life and the complex social phenomena that characterise it. The motivation is not merely out of curiosity, but also due to characterise it. The motive
theological motivations.
(Clark \& Lederle 1989:53-55). Pentecostals represent a community of prophets - the people baptised in the Spirit, as Luke describes the 1st-century church. They should appropriate the gift of prophecy to fulfil their potential as a charismatic community of prophets to challenge believers and secular society alike, rather than selfishly utilising the charismata for narcissistic purposes, trivialising both the phenomenon of prophecy and its content (Stronstad 1997:75-77). The presence of the Spirit and the charismata should make the charismatic community a radical alternative community that changes its environment, expressed holistically in physical and emotional ways, for example by way of tears and laughter, tongues and prophecies, healings and deliverances, dancing and singing, shouting and participation in testimonies, and showing the affinity for oral expression within Pentecostal spirituality (Neumann 2012:199).

In this way, faith communities function as alternative 'cities' that, by utilising the weapons of the weak, set out to provide forms of socio-political and economic solidarity and bodily presence, especially to those living on the margins of the polis who are the most vulnerable to forces of exploitation and injustice. Prophetic politics recognises and announces that allegiances to the state are secondary to allegiance to God. It encourages Spirit-filled believers to explicitly and discerningly witness prophetically from below in the public square (Green 2016:160) and surrendering their autonomy in order to acknowledge their dependency on the Spirit (Pinnock 1993:21) - also in the South African 'naked public square', characterised by the absence of religion from both the political and civic arena.

However, prophetic politics is not only based on the witness of believers or their existence as the alternative society representing the kingdom of God. They employ also other ways of prophetic politics, including involvement in schools and education of different groups, clinics and hospitals, labour unions, self-help groups and development and relief organisations and by influencing personal morality, nurturing civic responsibility, working for the alleviation of poverty, promoting education and advocating for peace and justice (Yong 2017:248).

\section{Synthesis}

In response to Robert Vosloo's well-reasoned article (2019) about the necessity that prophetic witness should always be from below in solidarity with society to represent the perspective of weakness as a form of performative resistance, this article responds from a Pentecostal perspective. 'Prophecy' means something else for Pentecostals. Their non-cessationist or continuationist approach to the Bible means that they are committed to a Spirit-centred version of Christian faith, in Douglas Jacobsen's words (2003:12). They read the Bible not primarily to gain knowledge about ancient history or ideas, but because they expect to share the same kind of experiences and the same kind of relationship with God that the Bible witnessed to (Keener 2017:274). This implies that they read 
and understand texts according to their purposed function, but also as 'sources' by which one addresses other questions (Bultmann 1984:79), also allowing for the unique revelation of the Spirit, the 'voice of God', who applies a specific passage to a new situation. Van der Geest (1998:40) remarks that the two main ingredients of participant observation in reading the Bible are that one sees a person's life in the text and take part in it, and it only makes sense when it is accompanied by speaking and listening. When one speaks of the 'revelation of God', such participant observation is involved with a reciprocal relationship consisting of give and take by the two parties. In a cerebral reading of the Bible with accompanying rational evaluation of 'truth', such a relationship seems to be impossible. The Pentecostal hermeneutics also draws attention to Jesus' predilection for the marginalised, transforming them into change agents in the poor parts of society (Gerlach 1974:671; Hine 1974:652), allowing Gerlach (1974:672) to define Pentecostalism not as a 'reaction to change', but rather as a 'cause of change'. Pentecostalism is not a reactionary, but a revolutionary movement (Archer 2009:36) in the margins set apart from the larger Christian community by its distinct doctrine of Spirit baptism and speaking in tongues (Archer 2009:209; Keener 2016:54), allowing it to be involved in society by way of its prophetic politics.

\section{Acknowledgements Competing interests}

The author declares that he has no financial or personal relationship(s) which may have inappropriately influenced him in writing this article.

\section{References}

Anderson, A., 1996, 'The hermeneutical processes of Pentecostal-type African initiated churches in South Africa', Missionalia 24(2), 171-185.

Anderson, A., 2001, African reformation: African initiated Christianity in the 20th century, Africa World Press, Trenton, NJ.

Anderson, A.H., 1991, Moya: The Holy Spirit in an African context, Sigma, Pretoria. (Manualia didactica, 13)

Anderson, A.H., 2013, An introduction to Pentecostalism, 2nd edn., Cambridge University Press, Cambridge.

Anderson, A.H., 2016, 'The Spirit and the African spiritual world', in V. Synan A. Yong \& J.K. Asamoah-Gyadu (eds.), Global renewal Christianity: Spirit empowered movements past, present, and future, pp. 304-320, Charisma House, Lake Mary, FL.

Archer, K.J., 2009, A Pentecostal hermeneutic: Spirit, Scripture and community, CPT, Cleveland, $\mathrm{OH}$.

Asamoah-Gyadu, J.K., 2013, Contemporary Pentecostal Christianity: Interpretations from an African context, Wipf \& Stock, Eugene, OR.

Barrett, D.B., 2001, 'The worldwide Holy Spirit renewal', in V. Synan (ed.), The century of the Holy Spirit: 100 years of Pentecostal and charismatic renewal, pp. 381-414, Thomas Nelson, Nashville, TE.

Barrett, D.B., Johnson, T.M. \& Crossing, P.F., 2008, 'Missiometrics 2008: Reality checks for Christian world communions,' International Bulletin of Missionary Research 32(1), 27-31. https://doi.org/10.1177/239693930502900109

Bosch, D.J., 1975, 'The traditional religions of Africa: Study guide for MSR203', University of South Africa, Pretoria.

Bultmann, R., 1984, 'The problem of hermeneutics', in S.M. Ogden (ed.), New Testament mythology and other basic writings, pp. 69-93, Fortress, Philadelphia, PA.

Clark, M.S. \& Lederle, H.I., 1989, What is distinctive about Pentecostal theology?, University of South Africa, Pretoria.(Miscellanea Specialia 1)

Cox, H., 1995, Fire from heaven: The rise of Pentecostal spirituality and the reshaping of religion in the twenty-first century, Addison-Wesley, New York.

Daneel, M.L., 1987, Quest for belonging, Mambo, Gweru.
De Villiers, E., 2016, 'Do the prophetic and reformist approaches in Christian ethics exclude one another? A responsibility ethics attempt at reconciliation', in H. Kroesbergen (ed.), Prophecy today: Reflections from a Southern African H. Kroesbergen (ed.), Prophecy today: Reflections from
context, pp. 148-162, Christian Literature Fund, Wellington.

Frahm-Arp, M., 2016, 'The rise of the megachurches in South Africa', in V. Synan, A. Yong \& J.K. Asamoah-Gyadu (eds.), Global renewal Christianity: Spiritempowered movements past, present, and future, vol. 3, pp. 263-284, Charisma House, Lake Mary, FL.

Gerlach, L.P., 1974, 'Pentecostalism: Revolution or counter-revolution?', in I.I. Zaretsky \& M.P. Leone (eds.), Religious movements in contemporary America, pp. 669-699, Princeton University Press, Princeton, NJ.

Green, J.B. 2016, 'Pentecostal hermeneutics: A Wesleyan perspective', in K.J. Archer \& L.W. Oliverio (eds.), Constructive pneumatological hermeneutics in Pentecostal Christianity, pp. 159-174, Palgrave Macmillan, New York.

Hansen, L., Koopman, N. \& Vosloo, R., 2011, 'Introduction', in L. Hansen, N. Koopman \& R. Vosloo (eds.), Living theology: Essays presented to Dirk J. Smit on his sixtieth birthday, pp. ix-xviii, Bible Media, Wellington.

Hine, V.H., 1974, 'The deprivation and disorganization theories of social movements', in I.I. Zaretsky \& M.P. Leone (eds.), Religious movements in contemporary America, pp. 646-661, Princeton University Press, Princeton, NJ.

Institute for Contextual Theology, 1985, Speaking for ourselves, ICT, Braamfontein.

Jacobsen, D., 2003, Thinking in the Spirit: Theologies of the early Pentecostal movement, Indiana University Press, Bloomington, IN

Jacobsen, D., 2011, The world's Christians: Who they are, where they are, and how they got there, Wiley-Blackwell, West Sussex, UK.

Kärkkäinen, V.-M., 2002, Pneumatology: The Holy Spirit in ecumenical, international, and contextual perspective, Baker Academic, Grand Rapids, MI.

Kaunda, C.J., 2016, 'Enabling liminality prophetic witness to xenophobia: Proposing a missiological Spirit response for the church in South Africa', Koers - Bulletin for Christian Scholarship 81(1), 1-9. https://doi.org/10.19108/KOERS.81. 1.2217

Keener, C.S., 2016, Spirit hermeneutics: Reading Scripture in light of Pentecost, Eerdmans, Grand Rapids, MI.

Keener, C.S., 2017, 'Pentecostal biblical interpretation/Spirit hermeneutics', in M.J. Horman (ed.), Scripture and its interpretation: A global, ecumenical introduction to the Bible, pp. 270-283, Baker Academic, Grand Rapids, MI.

Mbiti, J.S., 1969, African religions and philosophy, Heinemann, London.

Moltmann, J., 1974, The crucified God: The cross of Christ as the foundation and criticism of Christian theology, transl. R.A. Wilson \& J. Bowden, Harper \& Row, New York.

Muindi, S.W., 2012, 'The nature and significance of prophecy in Pentecostalcharismatic experience: An empirical-biblical study', PhD dissertation, University of Birmingham.

Ndiokwere, N., 1981, Prophecy and revolution: The role of prophets in the African churches and in biblical tradition, SPCK, London.

Nel, M., 2017, 'The Pentecostal movement's view of the continuity of tongues in Acts and 1 Corinthians', In die Skriflig 51(1), a2198. https://doi.org/10.4102/ids. v51i1.2198

Neumann, P.D., 2012, 'Spirituality', in A. Stewart (ed.), Handbook of Pentecostal Christianity, pp. 195-201, NIU, DeKalb, IL.

Ngong, D.T., 2006, 'In quest of wholeness: African Christians in the new Christianity', Review \& Expositor 103(3), 519-540. https://doi.org/10.1177/0034637306 10300305

Omenyo, C., 2014, 'African Pentecostalism', in C.M. Robeck \& A. Young (eds.), The Cambridge companion to Pentecostalism, pp. 132-151, Cambridge University Press, New York.

Omenyo, C. \& Atiemo. A., 2006, 'Claiming religious space: The case of neo-Prophetism in Ghana', Ghana Bulletin of Theology New Series 1(1), 55-68.

Omenyo, C.N. \& Arthur, W.A., 2013, 'The Bible says! Neo-prophetic hermeneutics in Africa', Studies in World Christianity 19(1), 50-70. https://doi.org/10.3366/ swc.2013.0038

Pentecostal Resource Page, 2006, viewed 18 July 2018, from http://pewforum.org/ surveys/Pentecostal/

Pinnock, C.H., 1993, 'The work of the Holy Spirit in hermeneutics', Journal of Pentecostal Theology 1(2), 3-23. https://doi.org/10.1177/096673699300100201

Quayesi-Amakye, J., 2013, Christology and evil in Ghana: Towards a Pentecostal public theology, Rodopi, Amsterdam.

Quayesi-Amakye, J., 2016, "Nativizing" the gospel: Pentecostalism and theology in Africa', in V. Synan, A. Yong \& J.K. Asamoah-Gyadu (eds.), Global renewa Christianity: Spirit-empowered movements past, present, and future, vol. 3, pp. 287-303, Charisma House, Lake Mary, FL.

Shaw, M.R., 1997, The kingdom of God in Africa: A short history of African Christianity, Baker, Grand Rapids, MI.

Smith, C.L., 2014, 'The politics and economics of pentecostalism: A global survey', in C.M. Robeck \& A. Yong (eds.), The Cambridge companion to Pentecostalism, pp.175-194, Cambridge University Press, New York.

Stronstad, R., 1997, 'The prophethood of all believers: A study in Luke's charismatic theology', in W. Ma \& R.P. Menzies (eds.), Pentecostalism in context: Essays in honor of William W. Menzies, pp. 60-77, Sheffield Academic Press, Sheffield. 
Taylor, J.V., 1963, The primal vision: Christian presence and African religion, SCM, London.

Van der Geest, S., 1998, 'Participant observation in demographic research: Fieldwork experiences in a Ghanaian community', in A.M. Basu \& P. Aaby (eds.), The methods and uses of anthropological demography, pp. 39-56, Clarendon, Oxford.

Vosloo, R., 2013, 'Remembering the role of the reformed churches in the struggle for justice in South Africa (1960-1990): Some remarks on the promise and pitfalls of memory and historiography', in M.-A. Plaatjes-van Huffel \& R. Vosloo (eds.), pp. 15-25, SUN, Stellenbosch.

Vosloo, R., 2017, Reforming memory: Essays on South African church and theological history, SUN, Stellenbosch.
Vosloo, R., 2019, 'Prophetic witness in weakness', In die Skriflig 53(2), a2400. https:// doi.org/10.4102/ids.v53i2.2400

World Bank in South Africa, 2018, viewed 14 July 2018, from http://www.worldbank. org/en/country/southafrica/overview

Yong, A., 2010a, In the days of Caesar: Pentecostalism and political theology, William B. Eerdmans, Grand Rapids, MI.

Yong, A., 2010b, 'Pentecostalism and the political: Trajectories in its second century', Pneuma 32(3), 333-336. https://doi.org/10.1163/157007410X531880

Yong, A., 2017, The hermeneutical Spirit: Theological interpretation and scriptura imagination for the 21st Century, Cascade, Eugene, OR. 